\title{
EVALUASI DAN OPTIMALISASI INSTALASI PENGOLAHAN LINDI DI TPK SARIMUKTI
}

\section{PUTRI SAFRIA, ARIEF PERDANA}

\author{
Seksi Perencanaan Teknis dan Evaluasi UPTD Pengelolaan Sampah TPA/TPST Regional Dinas \\ Lingkungan Hidup Provinsi Jawa Barat \\ Email : putri.bpsr@gmail.com
}

\begin{abstract}
ABSTRAK
Instalasi Pengolahan Lindi (IPL) TPK Sarimukti terdiri dari Kolam Stabilisasi - Bak Pengumpul Kolam Anaerobic Buffle Reactor (ABR) - Kolam Aerobik - Kolam Sedimentasi dan Land Treatment dengan menerapkan pengolahan secara biologis. Evaluasi dilakukan dengan menganalisa kondisi eksisting baik secara kualitas, kuantitas lindi dan desain IPL kemudian membandingkan dengan standar baku mutu lindi PermenLHK No. 59/2016 dan Permen PU No. 3/2013 tentang Kriteria desain sarana dan prasarana penanganan sampah. Evaluasi IPL TPK Sarimukti tidak menunjukkan hasil yang diharapkan terlihat dari kondisi lindi secara fisik, kualitas lindi yang tidak mengalami penurunan parameter pencemar secara signifikan akibat beban organik yang tinggi dan unit pengolahan yang tidak sesuai dengan kriteria desain. Selain itu, nilai rasio BOD/COD:0,09-0,4 lindi IPL TPK Sarimukti menunjukkan tidak cukup hanya dengan pengolahan biologi. Oleh karena itu perlunya optimalisasi berupa perbaikan unit pengolahan, penambahan unit pre-treatment dan dilanjutkan dengan proses fisik-kimia. Rencana optimalisasi IPL TPK Sarimukti secara berurutan terdiri atas Kolam Stabilisasi - Bak Kontrol 1 - Reaktor AOP - Bak Kontrol 2 - Kolam ABR - Kolam Aerobik 1 - Kolam Aerobik 2 - Kolam Sedimentasi - Reaktor Filtrasi - Bak Effluen - Badan air yang berupa sungai.
\end{abstract}

Kata kunci: Lindi, IPL, Evaluasi, Optimalisasi

\begin{abstract}
TPK Sarimukti's Leachate Treatment Plant (IPL) consists of a Stabilization Pond - Collecting Tub Anaerobic Buffle Reactor (ABR) Pond - Aerobic Pond - Sedimentation Pond and Land Treatment by applying a biological treatment. The evaluation was carried out by analyzing the existing conditions both in quality, quantity of leachate and IPL design then comparing with the leachate quality standard PermenLHK No. 59/2016 and Minister of Public Works Regulation No.3/2013 concerning the criteria for the design of waste handling facilities and infrastructure. The evaluation of IPL TPK Sarimukti did not show the expected results seen from the physical leachate conditions, the quality of the leachate which did not experience a significant decrease in pollutant parameters due to high organic loads and the processing unit that did not meet the design criteria. In addition, the BOD / COD ratio 0,09-0,4 of IPL TPK Sarimukti leachate shows that biological processing alone is not sufficient. Therefore, optimization is needed in the form of repairing the processing unit, adding a pre-treatment unit and continuing with the physico-chemical process. The IPL optimization plan of the Sarimukti TPK sequentially consists of a stabilization pond - control basin 1 - AOP reactor control basin 2 - ABR pool - aerobic pool 1 - aerobic pool 2 - sedimentation pond - filtration reactor - effluent basin - water bodies in the form of rivers.
\end{abstract}

Keywords: Leachate, Lachate Treatmet Plant, Evaluation, Optimization 


\section{PENDAHULUAN}

Tempat Pengolahan Kompos (TPK) Sarimukti adalah Tempat Pengolahan dan Pemrosesan Akhir Sampah (TPPAS) yang dikelola UPTD Pengelolaan Sampah TPA/TPST Regional Jawa Barat yang melayani sampah di wilayah Metropolian Bandung Raya antara lain Kota Bandung, Kota Cimahi, Kabupaten Bandung Barat dan Kabupaten Bandung yang mulai beroperasi pada Tahun 2006. Semula TPK Sarimukti dioperasikan hingga tahun 2011, namun pemakaiannya diperpanjang hingga tahun 2023 dengan memaksimalkan pengolahan sampah secara composting dan semi sanitary landfill.

TPK Sarimukti dioperasikan dalam kondisi darurat sampah di wilayah metropolitan Bandung setelah longsornya TPA Leuwigajah. Pada saat awal masa operasi TPK Sarimukti tidak memiliki instalasi pengolahan lindi (IPL). Pada Tahun 2009, dibangun IPL yang terdiri dari kolam aerobik - kolam fakultatif - dan biofilter selanjutnya secara bertahap IPL TPK Sarimukti mengalami perbaikan dan pengembangan pengolahan secara fisik dan biologis yang terdiri dari Kolam Stabilisasi - Bak Pengumpul - Kolam Anaerobic Buffle Reactor (ABR) - Kolam Aerobik, Kolam Sedimentasi dan Land Treatment.

Berdasarkan hasil uji kualitas lindi yang diuji setiap bulan, IPL TPK Sarimukti belum menunjukkan hasil yang optimal jika dilihat dari kualitas lindi dioutlet IPL yang belum memenuhi standar baku mutu, Nilai BOD $190-1856 \mathrm{mg} / \mathrm{L}$ (baku mutu = $150 \mathrm{mg} / \mathrm{L}$ ) dan Nilai COD adalah $2.934-4.515 \mathrm{mg} / \mathrm{L}$ (baku mutu $=150 \mathrm{mg} / \mathrm{L}$ ) dengan kuantitas lindi yang sangat fluktuatif yaitu 4-14 L/detik akibat beban hidrolis (Q)/debit yang besar. Beban organik yang tinggi diperkirakan berasal dari hasil dekomposisi sampah organik pada tempat pengolahan kompos atau landfill serta masukan air eksternal. Hal ini sesuai dengan pernyataan Roshmini dkk (2018) bahwa pemanfaatan lahan serta aktivitasnya mempengaruhi kualitas air di wilayah tersebut yang artinya pemanfaatan lahan di areal TPK Sarimukti sebagai tempat pengurugan sampah dan pengolahan kompos menyebabkah kualitas lindi memiliki kandungan organik yang tinggi. Selain itu, kemungkinan lain yang menjadi penyebab kurang optimalnya kinerja setiap unit-unit pengolahan di IPL TPK Sarimukti. Oleh karena itu, diperlukan evaluasi sebagai bentuk perbaikan dan optimalisasi di IPL TPK Sarimukti. Tujuan dari studi ini adalah untuk mengevaluasi IPL di TPK Sarimukti dan memberikan rekomendasi teknis untuk optimalisasi IPL TPK Sarimukti. Hasil studi ini dapat digunakan untuk memperoleh solusi teknis agar TPK Sarimukti dapat mengolah air lindi dengan baik dan optimal dan memenuhi standar baku mutu sebelum dialirkan ke badan air penerima.

\section{BAHAN DAN METODE}

\subsection{Studi Literatur dan Pengumpulan}

Studi literatur bertujuan untuk mengetahui karakteristik air lindi, kondisi umum IPL di Indonesia, teknologi pengolahan air limbah serta pengumpulan data kondisi eksisting pengolahan lindi di IPL TPK Sarimukti.

\subsection{Analisis Kualitas dan Kuantitas Lindi}

Pengujian kualitas lindi dilakukan pada 4 (empat) titik di setiap unit di IPL yaitu di inlet kolam stabilisasi, outlet kolam anaerobik, outlet kolam aerobik dan outlet IPL. Titik pengujian tersebut dipilih agar dapat melihat efisiensi pengolahan di setiap kolam. Parameter yang diukur meliputi TSS, pH, Kadmium BOD, COD, TSS, $\mathrm{N}$ Total dan Kadmium. Data pengujian yang digunakan adalah data dalam 6 (enam) bulan terakhir pada tahun 2019 di Dinas Lingkungan Hidup dan kemudian dianalisa dengan merujuk pada Peraturan Menteri 
Lingkungan Hidup dan Kehutanan Nomor 59 Tahun 2016 tentang Baku Mutu Lindi bagi usaha dan/atau Kegiatan Tempat Pemrosesan Akhir sedangkan kuantitas lindi diketahui dengan cara pengukuran debit lindi TPK Sarimukti secara periodik. Pengukuran debit dilakukan oleh pengelola IPL TPK Sarimukti yang dilakukan secara reguler setiap bulan. Pengukuran dilakukan pada inlet dan outlet kolam stabilisasi yang hanya dilakukan selama 3 jam, dan diasumsikan fluktuasi selama pengukuran terus berulang selama 24 jam.

\subsection{Evaluasi Desain IPL}

Evaluasi terhadap desain IPL dilakukan untuk mengetahui kinerja setiap unit operasi dan unit proses. Tahapan evaluasi dilakukan dengan mengumpulkan data kondisi eksisting kemudian dilakukan perhitungan yang meliputi dimensi unit. Setelah dilakukan pengumpulan data dan perhitungan maka hasilnya akan dibandingkan dengan kriteria desain berdasarkan Peraturan Menteri Pekerjaan Umum Nomor 03 Tahun 2013 tentang Penyelenggaraan Prasarana dan Sarana Persampahan Dalam Penanganan Sampah Rumah Tangga dan Sampah Sejenis Sampah Rumah Tangga untuk kemudian dievaluasi guna mengetahui kinerja setiap unit dan rencana optimalisasi IPL.

\section{HASIL DAN PEMBAHASAN}

\subsection{Analisa Kualitas Lindi}

Menurut Peraturan Menteri Lingkungan Hidup dan Kehutanan Nomor 59 Tahun 2016, Lindi adalah limbah cair yang timbul akibat masuknya air eksternal ke dalam timbulan sampah, melarutkan dan membilas materi-materi terlarut, termasuk juga materi organik hasil proses dekomposisi biologis. Air lindi dapat didefinisikan sebagai cairan yang menginfiltrasi melalui tumpukan sampah dan telah mengekstraksi material terlarut maupun tersuspensi (Tchobanoglous, 2013). Hasil pengukuran dan efisiensi pengolahan lindi dapat dilihat pada Tabel 1.

Tabel 1. Kualitas Lindi dan Efisiensi Pengolahan Lindi di IPL TPK Sarimukti

\begin{tabular}{|c|c|c|c|c|c|c|c|c|c|}
\hline \multirow{2}{*}{ No } & \multirow{2}{*}{ Parameter } & \multirow{2}{*}{$\begin{array}{c}\text { Inlet } \\
\text { Range }\end{array}$} & \multicolumn{2}{|c|}{ Kolam Anaerobik } & \multicolumn{2}{|c|}{ Kolam Aerobik } & \multicolumn{2}{|c|}{ Outlet } & \multirow{2}{*}{$\begin{array}{l}\text { Baku } \\
\text { Mutu }\end{array}$} \\
\hline & & & Range & $\begin{array}{c}\text { Efisiensi } \\
(\%)\end{array}$ & Range & $\begin{array}{c}\text { Efisiensi } \\
(\%)\end{array}$ & Range & $\begin{array}{c}\text { Efisiensi } \\
(\%)\end{array}$ & \\
\hline 1 & TSS (mg/L) & $17-65$ & $18-33$ & $(-35)-68$ & $57-99$ & $(-421)-(-5)$ & $35-71$ & $(-318)-11$ & 100 \\
\hline 2 & $\mathrm{pH}$ & $7.9-8.1$ & $8.2-8.6$ & $(-6)-(-1)$ & $8.3-8.5$ & $(-6)-(-2)$ & $8.3-8.5$ & $(-6)-(-4)$ & $6-9$ \\
\hline 3 & Kadmium (mg/L) & $0.01-0.02$ & $0.01-0.02$ & $(-100)-(0)$ & $0.01-00.2$ & $(-100)-(-0)$ & $0.01-0.02$ & $(-100)-50$ & 0,1 \\
\hline 4 & $\mathrm{BOD}_{5}(\mathrm{mg} / \mathrm{L})$ & $355-2292$ & $301-1573$ & $(-1)-62$ & $227-1565$ & $(-6)-62$ & $194-1856$ & $(-25)-64$ & 150 \\
\hline 5 & COD (mg/L) & $3892-4792$ & $3864-4581$ & $(-1)-16$ & $2843-4274$ & $(-9)-38$ & $2934-4515$ & $(-6)-36$ & 300 \\
\hline 6 & $\mathrm{~N}$ total (mg/L) & $2779-3673$ & 60-2997 & $18-98$ & $2199-2828$ & $(-2)-24$ & $2151-2610$ & $17-30$ & 60 \\
\hline
\end{tabular}

Nilai TSS yang didapat pada seluruh titik pengujian masih memenuhi baku mutu. Namun hal yang harus diperhatikan adalah jika mengamati alur pengolahan lindi yang dimulai pada titik inlet, kolam anaerobik, hingga kolam aerasi, kadar TSS justru mengalami peningkatan dan baru mengalami penurunan pada saat lindi berada di titik outlet, dapat dilihat dari tingkat efisiensi pengolahan di setiap unit pengolahan yang sangat kecil. Hal ini terjadi diduga akibat adanya limpasan air eksternal yang masuk bersama lumpur dan tanah ke dalam kolam stabilisasi, anaerobik dan aerobik. Hal lain yang patut dipertimbangkan adalah adanya mikroorganisme dari proses pengolahan anaerobik maupun aerobik yang terukur sebagai TSS, apalagi IPL ini tidak disertai proses sirkulasi lumpur. Hal tersebutlah yang memungkinkan menjadi penyebab nilai TSS jadi meningkat dari kolam satu ke kolam lainnya. 
Nilai pH di kisaran 7,9-8,6 yang menunjukkan bahwa lindi mempunyai sifat cenderung basa seperti diinformasikan Renou dkk (2008) untuk TPA dengan timbunan yang tua ( $>10$ tahun) akan memiliki $\mathrm{pH}$ lindi yang lebih besar dari 7,5. Kondisi ini sebenarnya menguntungkan karena nilai $\mathrm{pH}$ masih berada pada rentang $\mathrm{pH}$ yang cocok untuk proses pengolahan biologi yaitu 6-9. Selain itu nilai tersebut masih memenuhi baku mutu dengan standar yang ditetapkan sebesar 6-9. Kadmium adalah logam yang digunakan pada industri baterai, coating, pigmen, sintetik dan plastik. Kadmium di tumpukkan TPK Sarimukti adalah masih memenuhi baku mutu sejak dari inlet sampai ke outlet IPL Hal ini disebabkan karena sumber sampah di TPK Sarimukti yang berasal dari domestik dan hasil studi komposisi sampah yang dilakukan JICA di TPK Sarimukti pada Tahun 2011, sampah yang mengandung logam hanya sekitar 0,1\%. BOD memiliki standar baku mutu sebesar $150 \mathrm{mg} / \mathrm{L}$, sedangkan lindi TPK Sarimukti memiliki nilai BOD dengan kisaran $355-2292 \mathrm{mg} / \mathrm{L}$ pada titik inlet (lindi belum terolah). Artinya lindi fresh TPK Sarimukti memiliki karakteristik BOD yang melebihi baku mutu. Jika melihat pada efesiensi penurunan BOD dari kolam satu ke kolam lainnya, terjadi penurunan kadar BOD namun tidak terlalu signifikan. Dimana pada kolam anaerobik efisiensi pengolahan yang mampu dicapai pada kisaran (-1)\%-62\% yang artinya kolam anaerobik hanya mampu menurunkan kadar BOD maksimal sebesar $62 \%$ namun dalam kondisi tertentu terjadi peningkatan kadar BOD sebesar $-1 \%$. Sama halnya dengan kolam aerasi dimana efisiensi pengolahan yang mampu dicapai pada kisaran $(-6) \%-62 \%$ dan pada titik outlet sebesar (-25)\%-64\%. Kadar BOD pada titik outlet pun berada dalam kisaran 194-1856 $\mathrm{mg} / \mathrm{L}$ yang artinya masih melebihi baku mutu.

COD memiliki standar baku mutu sebesar $300 \mathrm{mg} / \mathrm{L}$, lindi TPK Sarimukti pada titik inlet (lindi belum terolah) memiliki nilai COD dengan kisaran 3892-4792 mg/L sehinga dikategorikan melebihi baku mutu. Sama halnya dengan parameter BOD, terjadi efisiensi penurunan COD dari kolam satu ke kolam lainnya namun tidak terlalu signifikan. Dimana pada kolam anaerobik efisiensi pengolahan yang mampu dicapai pada kisaran (-1)\%-16\% yang artinya kolam anaerobik hanya mampu menurunkan kadar BOD maksimal sebesar $16 \%$ namun dalam kondisi tertentu terjadi peningkatan kadar BOD sebesar $-1 \%$. Sama halnya dengan kolam aerasi dimana efisiensi pengolahan yang mampu dicapai pada kisaran (-9)\%-38\% dan pada titik outlet sebesar (-6)\%-36\%. Kadar COD pada titik outlet pun berada dalam kisaran 2943-4515 mg/L yang artinya masih jauh melebihi baku mutu. $\mathrm{N}$ total, kandungan nitrogen dalam badan air baik dalam bentuk Amonia $\left(\mathrm{NH}_{3}\right)$, Nitrat $\left(\mathrm{NO}_{3}\right)$ dan Nitrit $\left(\mathrm{NO}_{2}\right)$ sangat berpengaruh terhadap kualitas suatu badan air. Siklus-siklus nitrogen yang terjadi dalam suatu badan air terkadang mengkonsumsi paling banyak oksigen terlarut dibandingkan dengan reaksi-reaksi biokimia lain yang terjadi dalam air. Keberadaan nitrogen dalam bentuk persenyawaannya cukup berperan dalam proses memperburuk kualitas perairan, sebab dalam batas-batas konsentrasi dan bentuk tertentu senyawa ini dapat bersifat racun bagi organisme perairan. Dalam hal ini hasil pengukuran pada titik outlet sebesar $2151-2610$ $\mathrm{mg} / \mathrm{L}$ yang melebihi standar yang ditetapkan sebesar $60 \mathrm{mg} / \mathrm{L}$.

Hasil evaluasi karateristik lindi menunjukan bahwa beberapa parameter pencemar seperti $\mathrm{BOD}, \mathrm{COD}, \mathrm{N}$ total masih melebihi standar baku mutu yang ditetapkan selain itu secara fisik pun lindi yang ada tidak mengalami perubahan warna yang signifikan dari unit pengolahan satu ke unit pengolahan lainnya. Jika melihat perbandingan BOD/COD adalah 0,09-0,4 menunjukkan bahwa pengolahan yang dilakukan sebaiknya menggunakan pengolahan secara kimia atau adanya penambahan unit operasi atau proses kimia yang dijadikan sebagai pre-treamnent untuk menaikkan perbandingan rasio BOD/COD.

\subsection{Hasil Pengukuran Debit}


Debit lindi yang dihasilkan cukup bervariasi, dimana pada titik inlet debit terkecil mencapai 4,00 liter/detik yang terjadi pada bulan September 2019 sedangkan debit terbesar yang dicapai sebesar 14,20 liter/detik terjadi pada bulan Februari 2019. Kondisi ini dipengaruhi oleh pola hujan moonson yang memang mencapai minimum sekitar bulan September dan maksimum di bulan Febuari. Rata-rata debit maksimum pada inlet sebesar 9,09 L/detik. Hal penting yang diinformasikan pada Tabel 2 adalah seringkali tercatat debit outlet lebih tinggi dari debit inlet. Penyelidikan fenomena tersebut dilakukan melalui neraca masa dan hasil pengukuran mengkonfirmasi bahwa debit outlet di kolam stabilisasi lebih besar dari debit inlet dikarenakan adanya masukan lain dari pipa yang memasuki kolam selain dari titik inlet utama sebanyak \pm 2 L/detik.

Tabel 2. Pengukuran Debit Lindi di TPK Sarimukti Tahun 2019

\begin{tabular}{cccccc}
\hline \multirow{2}{*}{ No } & \multirow{2}{*}{ Bulan } & \multicolumn{4}{c}{ Debit Lindi (Lt/Det) } \\
\cline { 3 - 6 } & & \multicolumn{2}{c}{ Inlet } & \multicolumn{2}{c}{ Outlet } \\
\cline { 3 - 6 } & & Min & Max & Min & Max \\
\hline 1 & Januari & 7.14 & 11.76 & 7.81 & 11.76 \\
\hline 2 & Februari & 10.05 & 14.20 & 10.50 & 14.21 \\
\hline 3 & Maret & 10.30 & 12.26 & 10.30 & 12.04 \\
\hline 4 & April & 7.14 & 11.76 & 7.14 & 12.50 \\
\hline 5 & Mei & 7.40 & 11.11 & 7.11 & 11.11 \\
\hline 6 & Juni & 7.14 & 8.69 & 7.11 & 9.09 \\
\hline 7 & Juli & 4.44 & 5.76 & 5.23 & 5.71 \\
\hline 8 & Agustus & 4,76 & 4.81 & 4.65 & 4.75 \\
\hline 9 & September & 4.00 & 4.87 & 3.92 & 6.55 \\
\hline 10 & Oktober & 6.25 & 7.14 & 6.66 & 7.14 \\
\hline 11 & November & 7.14 & 8.69 & 7.11 & 9.09 \\
\hline 12 & Desember & 7.89 & 7.98 & 7.95 & 8.03 \\
\hline & Rata-rata & 6,97 & 9.09 & 7.12 & 9.33 \\
\hline & Minimum & 4.00 & & 3,92 & \\
\hline & Maksimum & & 14,20 & & 14.21 \\
\hline
\end{tabular}

\subsection{Evaluasi Desain IPL TPK Sarimukti}

IPL TPK Sarimukti terdiri dari Kolam Stabilisasi, Bak Pengumpul, Kolam Anaerobic Buffle Reactor $(A B R)$, Kolam Aerobik 1 dan 2, Kolam Sedimentasi dan Land Treatment. Evaluasi dilakukan dengan perhitungan debit minimum dan maksimum. Skema IPL dapat dilihat pada Gambar 1 sebagai berikut :

\section{Kolam Stabilisasi}

Kolam stabilisasi menjadi kolam pengolahan lindi pertama dalam susunan IPL di TPK Sarimukti yang memiliki fungsi untuk menurunkan kadar BOD, sedimentasi dan stabilisasi influen untuk dialirkan menuju kolam pengolahan lindi selanjutnya. Tabel 3. menunjukkan bahwa parameter kedalaman sudah memenuhi kriteria desain namun untuk parameter waktu detensi belum memenuhi kriteria desain baik dalam kondisi debit minimum maupun maksimum. Waktu detensi yang singkat akan menyebabkan tidak optimalnya penyisihan BOD, dapat dilihat pada Tabel 1 yaitu efisiensi penyisihan BOD pada kolam ini sangat kecil hanya sebesar -1 - 62\% dengan nilai BOD adalah 355 - $2292 \mathrm{mg} / \mathrm{L}$. Berdasarkan hasil pengamatan kondisi eksisting, konstruksi bangunan kolam ini terlihat kurang baik, pola aliran tidak merata, adanya masukan lain selain dari titik inlet utama terlihat dari debit outlet lebih besar dari debit inlet yang ditunjukkan di Tabel 2 sehingga fungsi sebagai sedimentasi dan stabilisasi influen tidak efektif. Kolam ini perlu dilakukan redesain dengan harapan dapat 
mengejar kriteria waktu detensi dengan cara merubah pola aliran serta mengatur debit agar ke unit pengolahan berikutnya dengan memaksimalkan kolam ini sebagai pre-tretament.

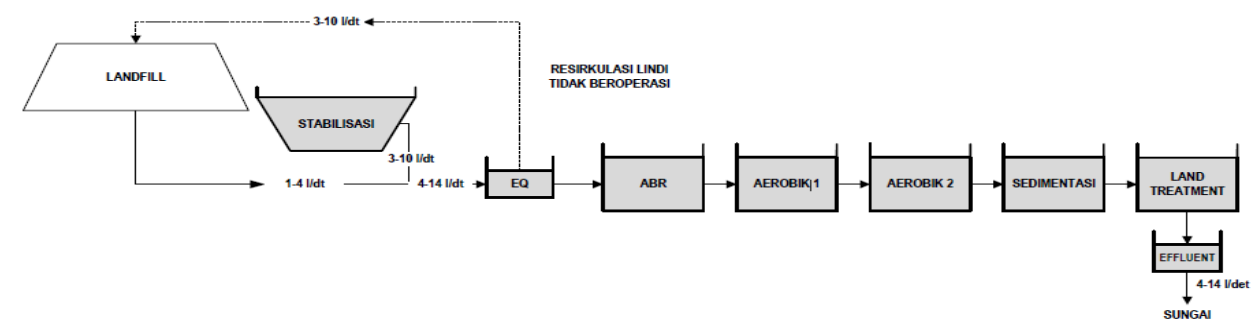

\section{Gambar 1. Skema IPL Eksisting TPK Sarimukti}

Tabel 3. Perbadingan Desain Eksisting dengan Kriteria Desain Kolam Stabilisasi

\begin{tabular}{|c|c|c|c|c|c|c|c|}
\hline \multirow[t]{2}{*}{ No } & \multirow[t]{2}{*}{ Parameter } & \multirow[t]{2}{*}{ Satuan } & \multicolumn{2}{|c|}{ Desain Eksisting } & \multirow[t]{2}{*}{ Kriteria Desain } & \multirow[t]{2}{*}{ Sumber } & \multirow[t]{2}{*}{ Keterangan } \\
\hline & & & Min & Max & & & \\
\hline 1 & Debit (Q) & It/det & 4 & 14.20 & & & \\
\hline 2 & Luas Permukaan & $m^{2}$ & 1.932 & 1.932 & & & \\
\hline 3 & Kedalaman & $\mathrm{M}$ & 3.00 & 3.00 & $2.5-5.0$ & Permen PU 3/2013 & Memenuhi \\
\hline 4 & Volume & $\mathrm{m}^{3}$ & 5796 & 5796 & & & \\
\hline \multirow[t]{2}{*}{5} & Waktu Detensi (Td) & Hari & 16.77 & 4.72 & $20-50$ & Permen PU 3/2013 & Tidak memenuhi \\
\hline & & Jam & 402.50 & 113.38 & $480-1200$ & Permen PU 3/2013 & \\
\hline
\end{tabular}

\section{Kolam Anaerobic Baffled Reactor (ABR)}

ABR atau tangki septik bersusun adalah teknologi tangki septik yang dimodifikasi dengan menambah beberapa kompartemen untuk menghasilkan aliran ke atas (upflow) melalui lumpur. Perbandingan desain eksisting dengan kriteria desain pada Tabel 4 menunjukkan untuk parameter kedalaman dan waktu detensi sudah memenuhi kriteria desain namun berbanding terbalik dengan parameter organic loading rate (OLR) atau beban organik yang dicapai (Beban COD yang tersisihkan). OLR yang mampu tersisihkan pada kondisi debit minimal hanya sebesar $0.01 \mathrm{~kg} / \mathrm{m}^{3}$.hari dengan efisiensi penyisihan hanya $1 \%$ padahal waktu detensi yang dicapai hingga 4.55 hari. Sedangkan pada kondisi debit maksimal waktu detensi yang dicapai selama 1.28 hari dengan nilai OLR $0.16 \mathrm{~kg} / \mathrm{m}^{3}$.hari yang artinya nilai OLR belum memenuhi kriteria yang ditetapkan oleh Permen PU 3/2013 yaitu sebesar 4.0$14.0 \mathrm{~kg} / \mathrm{m}^{3}$.hari. Masalah pada kolam anaerobik adalah waktu detensi tidak tercapai karena debit yang berlebih dan nilai BOD/COD $=0,1$ yang artinya makanan untuk bakteri tidak ada sehingga tidak cocok untuk pengolahan secara biologis (standar $B O D / C O D=0,5$ ). Berdasarkan pengamatan kondisi eksisting adalah masih banyaknya lumpur, cloging di media sarang tawon dan tidak adanya pola pembuangan lumpur. Beban organik yang berlebih di kolam ini dapat diatasi dengan melakukan perbaikan kolam stabilisasi sebagai pre-treatment atau penambahan unit pengolahan secara fisik-kimia dengan tujuan menaikkan rasio BOD/COD yang diinginkan untuk pengolahan secara biologis serta mengaktifkan kembali pola pembuangan lumpur.

\section{Kolam Aerobik}

Kolam aerobik merupakan unit pengolahan ketiga pada IPL TPK Sarimukti. Tabel 5 menunjukkan bahwa untuk parameter kedalaman sudah memenuhi kriteria desain, sedangkan waktu detensi masih terlihat belum mencapai kriteria desain pada saat kondisi debit maksimum. Parameter OLR atau beban organik/COD yang tersisihkan juga belum mampu mencapai kriteria desain. Efisiensi penurunan parameter pencemar yang mampu 
dicapai dengan nilai tertinggi adalah sebesar $26 \%$ terjadi pada kondisi debit minimum dengan nilai OLR $0,12 \mathrm{~kg} / \mathrm{m}^{3}$.hari yang artinya belum memenuhi kriteria yang ditetapkan dalam Permen PU 3/2013 yaitu 0,32-0,64 kg/m $\mathrm{m}^{3}$. Masalah pada kolam aerobik adalah beban pengolahan masih besar dapat dilihat pada Tabel 5, beban COD awal yang sangat besar yang disebabkan karena kurang efektifnya unit pengolahan sebelumnya. Selain inti masalah lain adalah kebutuhan oksigen tidak mempertimbangkan beban pengolahan karena aerator yang ada tidak berfungsi dengan baik, aliran udara tidak merata, dan tidak adanya pola pembuangan lumpur. Kolam ini perlu dilakukan perbaikan dengan mengfungsikan kembali aerator, pola aliran udara dan pola pembuangan lumpur.

Tabel 4. Perbandingan Desain Eksisting dengan Kriteria Desain Kolam ABR

\begin{tabular}{|c|c|c|c|c|c|c|c|}
\hline \multirow[t]{2}{*}{ No } & \multirow[t]{2}{*}{ Parameter } & \multirow[t]{2}{*}{ Satuan } & \multicolumn{2}{|c|}{ Desai Eksisting } & \multirow[t]{2}{*}{ Kriteria Desain } & \multirow[t]{2}{*}{ Sumber } & \multirow[t]{2}{*}{ Keterangan } \\
\hline & & & Min & Max & & & \\
\hline 1 & $\operatorname{Debit}(\mathrm{Q})$ & It/det & 4.00 & 14.20 & & & \\
\hline 2 & Kedalaman & M & 3.00 & 3.00 & $2.00-4.00$ & Permen PU 3/2013 & Memenuhi \\
\hline 3 & Beban COD tersisihkan/m³ & $\mathrm{kg} / \mathrm{m}^{3}$.hari & 0.01 & 0.16 & $4.00-14.00$ & Permen PU 3/2013 & Memenuhi \\
\hline 4 & Efisiensi & $\%$ & 1 & 4 & $70-85$ & Permen PU 3/2013 & Tidak memenuhi \\
\hline \multirow[t]{2}{*}{5} & Waktu Detensi (Td) & Hari & 4.55 & 1.28 & $1-2$ & Permen PU 3/2013 & Memenuhi \\
\hline & & Jam & 109.31 & 30.79 & $24-48$ & & \\
\hline
\end{tabular}

Tabel 5. Perbandingan Desain Eksisting dengan Kriteria Desain Kolam Aerobik

\begin{tabular}{|c|c|c|c|c|c|c|c|}
\hline \multirow[t]{2}{*}{ No } & \multirow[t]{2}{*}{ Parameter } & \multirow[t]{2}{*}{ Satuan } & \multicolumn{2}{|c|}{ Desain Eksisting } & \multirow{2}{*}{$\begin{array}{l}\text { Kriteria } \\
\text { Desain }\end{array}$} & \multirow[t]{2}{*}{ Sumber } & \multirow[t]{2}{*}{ Keterangan } \\
\hline & & & Min & Max & & & \\
\hline 1 & Debit (Q) & It/det & 4.00 & 14.20 & & & \\
\hline 2 & Kedalaman & $M$ & 3.00 & 3.00 & $1.80-6.00$ & Permen PU 3/2013 & Memenuhi \\
\hline 3 & Beban COD tersisihkan $/ \mathrm{m}^{3}$ & $\mathrm{~kg} / \mathrm{m}^{3}$.hari & 0.12 & 0.13 & $0.32-0.64$ & Permen PU 3/2013 & Tidak Memenuhi \\
\hline 4 & Efisiensi & $\%$ & 26 & 7 & $80-95$ & Permen PU 3/2013 & Tidak Memenuhi \\
\hline \multirow[t]{2}{*}{5} & Waktu Detensi (Td) & Hari & 8.69 & 2.45 & $3-10$ & Permen PU 3/2013 & Memenuhi \\
\hline & & Jam & 208.54 & 58.74 & $72-240$ & & \\
\hline
\end{tabular}

Tabel 6. Perbandingan Desain Eksisting dengan Kriteria Desain Kolam Sedimentasi

\begin{tabular}{|c|c|c|c|c|c|c|c|}
\hline \multirow[t]{2}{*}{ No } & \multirow[t]{2}{*}{ Parameter } & \multirow[t]{2}{*}{ Satuan } & \multicolumn{2}{|c|}{ Desain Eksisting } & \multirow{2}{*}{$\begin{array}{l}\text { Kriteria } \\
\text { Desain }\end{array}$} & \multirow[t]{2}{*}{ Sumber } & \multirow[t]{2}{*}{ Keterangan } \\
\hline & & & Min & Max & & & \\
\hline 1 & Debit (Q) & It/det & 4.00 & 14.20 & & & \\
\hline 2 & Beban COD Awal & $\mathrm{kg} / \mathrm{hari}$ & 983 & 5244 & & & \\
\hline 3 & Kedalaman & M & 2.75 & 2.75 & $3.00-5.00$ & Permen PU 3/2013 & Tidak Memenuhi \\
\hline \multirow[t]{2}{*}{4} & Waktu Detensi (Td) & Hari & 2.78 & 0.78 & $0.06-0.13$ & Permen PU 3/2013 & Tidak Memenuhi \\
\hline & & Jam & 66.71 & 18.79 & $1.5-3$ & Permen PU 3/2013 & Tidak Memenuhi \\
\hline 5 & Beban Hidrolik & $\mathrm{m}^{3} / \mathrm{m}^{2}$.hari & 0.80 & 2.84 & $20-50$ & Permen PU 3/2013 & Tidak Memenuhi \\
\hline
\end{tabular}

\section{Kolam Sedimentasi}

Kolam sedimentasi adalah unit operasi yang berfungsi untuk menghilangkan materi tersuspensi atau flok kimia secara gravitasi. Tabel 6 menunjukkan bahwa desain eksisting kolam sedimentasi belum memenuhi kriteria desain untuk parameter kedalaman, waktu detensi dan beban hidrolik. Selain itu, beban COD awal yang masih tinggi yang diperkirakan 
karena tidak efektifnya unit pengolahan sebelumnya. Kolam ini perlu dilakukan redesain perbaikan dimensi kolam sehingga volume yang ada mampu memenuhi fluktuasi debit yang ada dan dapat menyisihkan beban organik yang tinggi.

\section{Land Treatment}

Land Treatment atau kolam wet land merupakan unit pengolahan terakhir pada sistem IPL TPK Sarimukti. Kolam ini berfungsi menurunkan kandungan pencemar melalui kemampuan tanah untuk menyerap zat pencemar (filtrasi) dan melalui aktivitas bakteri. Namun eksistingnya, tidak ada media filtrasi apapun yang digunakan pada kolam ini. Hal ini tentu akan sangat mempengaruhi kemampuan kolam dalam menurunkan parameter pencemar yang ada. Tabel 7 menunjukkan bahwa waktu detensi yang sangat singkat menyebabkan besarnya efisiensi penyisihan COD menjadi rendah. Parameter kedalaman air telah memenuhi kriteria desain. Namun dengan tidak adanya media filtrasi apapun yang menjadi fungsi dasar wetland menyebabkan tidak terjadinya pengolahan yang diharapkan. Efisiensi pengolahan pada kondisi debit maksimum menghasilkan nilai yang negatif sebesar $-6 \%$ yang artinya pada kolam ini beban COD meningkat dibandingkan beban sebelumnya. Berdasarkan hasil evaluasi, kolam wetland pada IPL TPK Sarimukti harus dilakukan redesain sehingga parameter waktu detensi, beban COD, dan beban hidrolis bisa terpenuhi.

Tabel 7. Perbandingan Desain Eksisting dengan Kriteria Desain Kolam Wetland

\begin{tabular}{|c|c|c|c|c|c|c|c|}
\hline \multirow[t]{2}{*}{ No } & \multirow[t]{2}{*}{ Parameter } & \multirow[t]{2}{*}{ Satuan } & \multicolumn{2}{|c|}{ Desain Eksisting } & \multirow[t]{2}{*}{ Kriteria Desain } & \multirow[t]{2}{*}{ Sumber } & \multirow[t]{2}{*}{ Keterangan } \\
\hline & & & Min & Max & & & \\
\hline 1 & $\operatorname{Debit}(\mathrm{Q})$ & It/det & 4.00 & 14.20 & & & \\
\hline 2 & Kedalaman & $\mathrm{M}$ & 1.50 & 1.50 & $0.1-0.6$ & Permen PU 3/2013 & Tidak Memenuhi \\
\hline 3 & Beban COD tersisihkan/m³ & kg/ha.hari & 0.38 & -0.89 & & & \\
\hline 4 & Efisiensi & $\%$ & 15 & -6 & & & \\
\hline \multirow[t]{2}{*}{5} & Waktu Detensi (Td) & Hari & 1.45 & 0.41 & $4-15$ & Permen PU 3/2013 & Tidak Memenuhi \\
\hline & & Jam & 34.79 & 9.80 & $36-72$ & & \\
\hline
\end{tabular}

\subsection{Rencana Optimalisasi IPL TPK Sarimukti}

Berdasarkan hasil evaluasi seluruh unit pengolahan memiliki permasalahannya masingmasing. Selain itu, hasil pengolahan lindi eksisting yang diterapkan di IPL TPK Sarimukti yang menerapkan sistem pengolahan biologi pada secondary treatment tidak menunjukkan efisiensi yang diharapkan. Hal ini terlihat dari kondisi lindi secara fisik maupun hasil analisa kualitas lindi dimana kualitas lindi pada inlet hingga outlet IPL tidak mengalami penurunan parameter pencemar secara signifikan. Maka dapat disimpulkan bahwa lindi yang dihasilkan oleh IPL TPK Sarimukti tidak dapat diolah dengan pengolahan biologi tanpa adanya pretreatment yang dapat memperbaiki kualitas lindi hingga siap diolah secara biologi. Hal ini disebabkan karena nilai BOD/COD yang rendah menyebabkan treatment yang dipilih tidak mungkin hanya dengan sistem biologi saja diperlukan adanya kombinasi pengolahan dalam upaya meningkatkan efisiensi pengolahan. Idealnya sistem pengolahan perlu dikombinasikan dengan sistem fisik-kimia sehingga dapat memperbaiki kualitas lindi sehingga siap pada proses pengolahan selanjutnya.

Gambar 2 menunjukkan skema rencana optimalisasi berupa penambahan pre-treatment dan dilanjutkan dengan proses fisik-kimia. Pre-treatment yang akan diterapkan diharapkan dapat memaksimalkan kolam stabilisasi dan penambahan unit advanced oxidation process (AOP) sebagai proses fisik-kimianya yang dilengkapi bak kontrol 2 sebagai bak outlet dari unit AOP. Selain itu kolam wetland yang sebelumnya ada dalam IPL akan beralih fungsi sebagai bak effluen dengan adanya penambahan reaktor filtrasi. Sehingga rencana optimalisasi IPL TPK 
Sarimukti secara berurutan terdiri atas Kolam Stabilisasi - Bak Kontrol 1 - Reaktor AOP Bak Kontrol 2 - Kolam ABR - Kolam Aerobik 1 - Kolam Aerobik 2 - Kolam Sedimentasi Reaktor Filtrasi - Bak Effluen - Badan air yang berupa sungai.

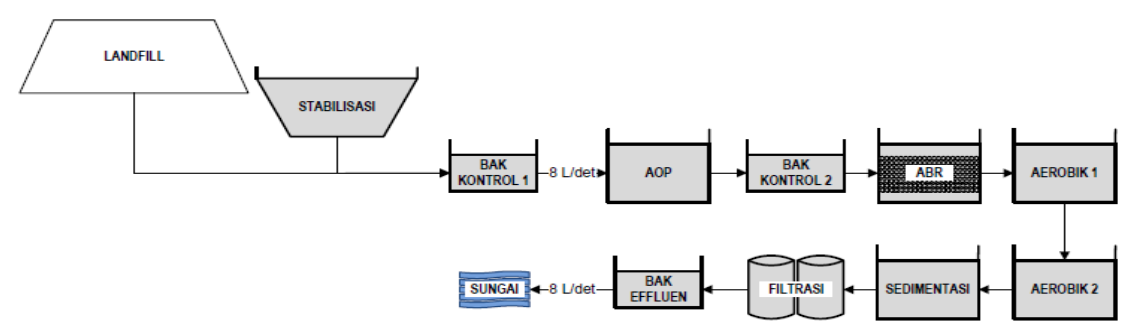

\section{Gambar 2. Skema Rencana Optimasi IPL TPK Sarimukti}

\section{Kolam Stabilisasi}

Kolam stabilisasi akan difungsikan sebagai tangki aliran rata-rata (TAR) untuk mengatur debit mengingat kolam stabilisasi memiliki kapasitas tampung yang cukup besar diharapkan dapat menampung kelebihan debit $(\Delta \mathrm{V})$ baik dalam kondisi debit maksimal maupun minimal. Untuk dapat berfungsi sebagai TAR, kondisi aliran dalam kolam harus laminer (tenang) dengan dilakukan perhitungan bilangan Froud. Debit lindi harus terdistribusi secara merata maka dilakukan perbaikan pola aliran dengan merubah dan memperbaiki sekat-sekat yang ada mengingat sekat kolam eksisting telah mengalami penurunan. Perubahan desain sekat akan dikembangkan menjadi 2 sekat di aliran pertama dan dilanjutkan dengan 4 sekat di aliran ke 2. Selain itu, perlu adanya drainase atau tanggul pencegah air limpasan hujan di sekeliling bangunan kolam, mengingat pada saat hujan lebat seringkali terjadi limpasan air hujan dan membawa serta sampah masuk ke dalam kolam dan diharapkan dapat mencegah TSS masuk kembali ke dalam kolam. Adapun dinding kolam yang telah mengalami kerusakan perlu dilakukan perbaikan.

\section{Bak Kontrol 1}

Bak kontrol 1 berada pada posisi outlet kolam stabilisasi 1, juga sebagai inlet menuju reaktor AOP. Bak kontrol 1 selanjutnya akan difungsikan mengatur debit yang masuk untuk diolah selanjutnya sehingga pada bak ini diperlukan penambahan pintu air sebagai alat pengatur aliran debit. Saat ini lubang pipa inlet bak kontrol berada di posisi bawah sehingga fungsi kolam stabilisasi sebagai tangki aliran rata-rata menjadi terganggu. Untuk itu dalam rangka optimalisasi, bak kontrol eksisting akan dilakukan perbaikan desain dengan cara meninggikan konstruksi bak kontrol 1 dan memindahkan pipa inlet bak kontrol pada posisi atas dengan harapan dapat memperpanjang waktu tinggal lindi baik dalam bak kontrol 1 maupun kolam stabilisasi.

\section{AOP (Advanced Oxidation Process)}

Proses fisik-kimia AOP adalah proses oksidasi lanjut berbasiskan ozon. Proses ozonisasi dapat dioptimalkan dengan berbagai proses oksidasi lanjut (AOP) seperti penambahan peroksida $\left(\mathrm{H}_{2} \mathrm{O}_{2}\right)$, UV, dan ozonasi katalitik (Sururi dkk, 2014). AOP yang dipilih pada rencana optimalisasi ini adalah Proses AOP berbasiskan ozoznisasi dengan penambahan UV. Penelitian teknologi AOP telah dilakukan dalam skala laboratorium untuk mengetahui efektifitas waktu kontak ozon terhadap lindi. Adapun kondisi percobaan yang digunakan adalah voltage $=220 \mathrm{v} / 50 \mathrm{~Hz}$, Current $=0,26 \mathrm{~A}$, Air Flow $=16 \mathrm{~L} / \mathrm{min}$, Volume $=1$ Liter, $\mathrm{pH}$ Akhir $=9$, Suhu $=24^{\circ} \mathrm{C}$ dapat dilihat pada Gambar 3. 


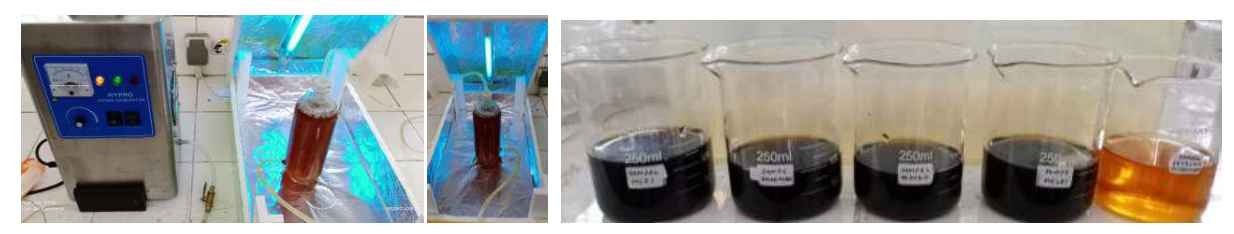

\section{Gambar 3. Kondisi Percobaan Teknologi AOP dalam Skala Laboratorium}

Dalam percobaan, waktu kontak ozonisasi terhadap lindi yang dibutuhkan hingga lindi dapat berubah warna menjadi lebih bening kecoklatan adalah selama 30 menit. Hasil percobaan menunjukkan adanya penurunan kosentrasi COD dari $4.581 \mathrm{mg} / \mathrm{L}$ menjadi $2.570 \mathrm{mg} / \mathrm{L}$ yang mana secara signigfikan dapat menaikkan rasio BOD/COD yang diinginkan untuk pengolahan secara biologi pada unit penggolahan berikutnya. Hal ini sesuai dengan penelitian Tizaoui dkk (2007) bahwa proses ozonisasi dengan AOP dapat menurunkan kadar COD dan meningkatkan kualitas lindi hingga siap untuk didegradasi secara biologi. Hal ini telah dibuktikan pada penelitian Sururi dkk, (2016) pengolahan lindi di TPK Sarimukti menggunakan AOP berbasiskan ozon dapat menurunkan kadar COD sebesar $77.78 \%$. Proses AOP berbasikan ozon ini dapat diptimalkan dengan menambahan katalis seperti dalam penelitian Safria, dkk (2016) dan Ramdhani dkk, (2018).

\section{Kolam Anaerobic Baffled Reactor(ABR)}

Tidak ada perbaikan desain pada kolam ini mengingat desain kolam ABR eksisting telah memenuhi kriteria yang dipersyaratkan. Kegagalan proses pengolahan terjadi akibat debit lindi yang berlebih menyebabkan waktu detensi menjadi tidak tercapai. Kendala tersebut dapat diatasi dengan menjaga debit yang masuk tetap di angka rata-rata. Hal ini telah dipersiapkan melalui pemasangan pintu air sejak pada kolam stabilisasi, bak kontrol 1 dan bak kontrol 2. Selain itu nilai BOD/COD yang rendah yaitu hanya 0,1 akan diatasi pada unit AOP dengan harapan dapat meningkatkan nilai BOD/COD mendekati standarnya sebesar 0,5 sehingga lindi siap untuk diolah pada unit ABR. Permasalahan terbesar yang terjadi dalam unit $A B R$ eksisting adalah kurangnya pemeliharaan yang ditunjukkan dengan masih banyaknya lumpur sehingga terjadi cloging di media sarang tawon dan tidak memiliki pola pembuangan dan resirkulasi lumpur yang menyebabkan media menjadi jenuh dan tidak dapat menjalankan fungsi sebagaimana mestinya. Untuk itu media sarang tawon lama akan dilakukan penggantian dengan media sarang tawon yang baru. Adapun dimensi media dan ketentuan aplikasi media sarang tawon tidak berubah dari kondisi eksisting. Adapun aplikasi media sarang tawon eksisting telah memenuhi kriteria ketentuan aplikasi media menurut BPPT dimana tinggi bed media pembiakan mikroba sebesar 0,9-1,5 meter sedangkan tinggi bed media eksisting telah mencapai batas atas kriteria setinggi 1,5 meter.

\section{Kolam Aerobik}

IPL TPK Sarimukti memiliki 2 buah kolam aerobik. Kolam aerobik 1 telah dilakukan perbaikan dengan memfungsikan kembali aerator dan memperbaiki pola aliran udaranya sedangkan kolam aerasi 2 belum dilakukan perbaikan. Kolam aerasi 1 dan 2 tidak dilakukan perubahan dimensi mengingat kedalaman dan waktu detensi eksisting sudah memenuhi kriteria yang dipersyaratkan. Kegagalan proses pengolahan terjadi akibat beban pengolahan yang masih besar serta kebutuhan udara belum dipertimbangkan terhadap beban pengolahannya. Maka optimalisasi dilakukan berupa kebutuhan udara untuk masing-masing kolam aerobik. Hasil perhitungan udara aktual pada debit rata-rata menunjukkan bahwa kebutuhanudara kolam aerobik $1\left(138,610 \mathrm{~m}^{3} /\right.$ hari) lebih besar jika dibandingkan dengan kolam aerobik $2(27,722$ $\mathrm{m}^{3}$ /hari) dikarenakan senyawa organik yang perlu disisihkan oleh kolam aerobik 1 lebih besar dibandingkan kolam aerobik 2 mengingat kolam aerobik 1 merupakan unit proses dengan 
urutan yang lebih awal. Semakin besar senyawa organik yg perlu disisihkan semakin besar pula kebutuhan udaranya.

\section{Kolam Sedimentasi}

Perbaikan pada kolam sedimentasi adalah perbaikan dimensi lebar dan kedalaman. Lebar berkurang sebesar 3 meter yang semula sebesar 18,45 m menjadi 15,45 m. Pengurangan lebar kolam dilakukan sebagai upaya pembagian lahan untuk lokasi penempatan reaktor AOP. Selain itu kedalaman kolam perlu diperdalam yang semula sedalam 2,75 meter menjadi 3 meter seperti yang telah ditetapkan pada kriteria desain. Untuk memperbaik kriteria beban hidrolik akan dilakukan dengan cara membagi kolam menjadi 4 (empat) chamber dengan harapan bahwa semakin besar nilai beban hidrolik yang mampu dicapai semakin besar pula efektifitas aliran yang dapat didistribusikan. Kondisi aliran pada kolam sedimentasi juga harus terjaga agar tetap tenang atau laminer. Kolam sedimentasi akan memiliki bak inlet dan bak outlet dengan lebar masing-masing bak sebesar 2 meter yang berada di samping kanan dan kiri kolam sedimentasi. Bak outlet sedimentasi tidak hanya bertugas mengalirkan lindi hasil treatment menuju pengolahan selanjutnya yaitu filtrasi namun juga berfungsi sebagai bak penampung lindi apabila rektor filtrasi mengalami cloging jika perlu dilakukan backwash.

\section{Filtrasi}

Unit proses friltrasi merupakan unit proses tambahan dalam rangka menyaring clogging dari unit sebelumnya yaitu unit sedimentasi. Unit filtrasi yang ditambahkan adalah berupa reaktor yang didalamnya berisi media filtrasi. Adapun media filtrasi yang digunakan berupa 2 (dua) media penyaring yaitu pasir dan antrasit. Tujuan filtrasi adalah untuk menghilangkan partikel yang tersuspensi dan koloidal dengan cara menyaringnya dengan media filter.

\section{Bak Effluen}

Bak effluen merupakan unit terakhir dari desain rencana IPL TPK Sarimukti. Bak ini menggantikan fungsi kolam wetland eksisting yaitu menurunkan kandungan pencemar melalui kemampuan tanah untuk menyerap zat pencemar (filtrasi) dan melalui aktivitas bakteri namun pada kondisi eksisting tidak memiliki media filter sehingga rencana optimalisasi sudah ditambah unit filtrasi sebelum melewati bak effluent. Bak ini nantinya akan berfungsi sebagai bak uji sebelum lindi terolah dialirkan menuju badan air. Pengujian dilakukan dengan menggunakan ikan sebagai media uji kualitas lindi yang telah melalui proses pengolahan.

\section{KESIMPULAN}

Berdasarkan hasil evaluasi, IPL TPK Sarimukti dengan pengolahan biologi tidak menunjukkan hasil yang optimal, terlihat dari kondisi lindi secara fisik, kualitas lindi pada inlet hingga outlet IPL yang tidak mengalami penurunan parameter pencemar secara signifikan akibat beban organik dan debit yang tinggi serta permasalahan unit pengolahan yang belum sesuai kriteria yang dipersyaratkan. Selain itu, Nilai BOD/COD yang rendah yaitu 0,09-0,4 menyebabkan pengolahan yang dipilih tidak mungkin hanya dengan sistem biologi saja namun perlu dikombinasikan dengan sistem fisik-kimia guna memperbaiki kualitas lindi pada proses pengolahan selanjutnya. Oleh karena itu, rencana optimalisasi adalah berupa penambahan pre-treatment dan dilanjutkan dengan proses fisik-kimia. Rencana optimalisasi IPL TPK Sarimukti secara berurutan terdiri dari Kolam Stabilisasi - Bak Kontrol 1 - Reaktor AOP - Bak Kontrol 2 - Kolam ABR - Kolam Aerobik 1 - Kolam Aerobik 2 - Kolam Sedimentasi - Reaktor Filtrasi - Bak Effluen - Badan air yang berupa sungai. Perlu adanya penelitian lanjut tentang pengolahan lindi di TPK Sarimukti dengan menggunkan AOP berbasiskan ozon skala lebih 
besar dengan mengkombinasikan dengan unit proses biologi dan fisik dengan tujuan dapat menekankan biaya operasional.

\section{UCAPAN TERIMA KASIH}

Unit Pengelolaan Sampah TPA/TPST Regional (UPTD PSTR) pada Dinas Lingkungan Hidup Provinsi Jawa Barat yang telah melakukan Kegiatan Peningkatan IPL TPK Sarimukti Tahun Anggaran 2020.

\section{DAFTAR RUJUKAN}

Peraturan Menteri Lingkungan Hidup dan Kehutanan Nomor 59 Tahun 2016 Tentang Baku Mutu Lindi Bagi Usaha dan/atau Kegiatan Tempat Pemrosesan Sampah.

Peraturan Menteri Pekerjaan Umum Republik Indonesia Nomor 03 Tahun 2013 Tentang Penyelenggaraan Prasarana dan Sarana Persampahan Dalam Penanganan Sampah Rumah Tangga dan Sampah Sejenis Sampah Rumah Tangga.

Ramdhani, M.Y, Sururi, M.R., Saleh, S.A. (2018). Leachate Treatment from Sarimukti Landfill Using Ozone with Sludge from Water Treatment Plant as a Catalyst. MATEC Web of Conferences 147 SIBE 2017, 04006.

Renou, S., Givaudan, J., Poulain, S., Dirassouyan, F., \& Moulin, P. (2008). Landfill leachate treatment: review and opportunity. Journal of hazardous material, 150, 468-493.

Roosmini, D., Notodarmojo, S., \& Sururi, M.R. (2018). The Characteristic of Natural Organic Matter (NOM) of Water from Cikapundung River Pond. IOP Conference Series : Earth and Environmental Science, 160, 012021.

Safria, P. (2016). Pengolahan Lindi Dengan Menggunakan Advanced Oxidation Process (AOP) Berbasiskan Ozon (O3/H2O2) Dengan Penambahan Zeolit Pada Kontaktor. Institut Teknologi Nasional, Bandung.

Sururi, M.R., Saleh, S.A., \& Safria, P. (2016). Leachate Treatment Using Advanced Oxidation Process with Zeolite as a Catalyst. 3rd International Postgraduate Conference on Biotechnology. ISBN 978-602-73103-1-5.

Sururi, M.R., Saleh, S.A., \& Krisna, A. (2014). Pengolahan Lindi Dengan Proses Oksidasi Lanjut Berbasis Ozon. Jurnal Reaktor, 15, 20-26.

Tizaoui, C., Bouselmi, L., Mansouri, L., \& Ghrabi, A. (2007). Landfill Leacheate With Ozone and Ozone/Hydrogen Peroxide System. Journal of Hazardous Materials, 140,316-324.

Tchobanoglous, G., Burton, F.L., \& Stensel, H.D. (2013). Water and Wastewater Engineering. Metcalf \& Eddy, Inc. 